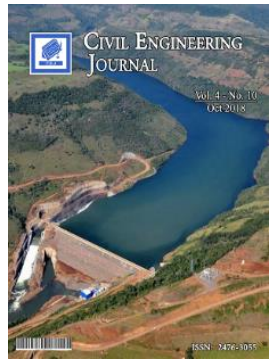

\title{
Traditional Climate Responsible Solutions in Iranian Ancient Architecture in Humid Region
}

\author{
Elham Mehrinejad Khotbehsara ${ }^{a^{*}}$, Fereshte Purshaban ${ }^{a}$, Sara Noormousavi Nasab ${ }^{\text {b }}$ \\ Abdollah Baghaei Daemei a , Pegah Eghbal Yakhdani a, Ramin Vali ${ }^{\mathrm{c}}$ \\ ${ }^{a}$ Department of Architecture, Rasht Branch, Islamic Azad University, Guilan, Iran \\ ${ }^{b}$ Department of Architecture, University of Guilan, Guilan, Iran
}

${ }^{c}$ Department of Civil Engineering, Faculty of Shahid Mohajer, Isfahan Branch, Technical and Vocational University (TVU), Isfahan, Iran

Received 26 June 2018; Accepted 07 October 2018

\begin{abstract}
The climatically compatible design is one of the closest ways getting the optimum use of renewable sources of energy since consideration to climatic conditions is the main concern in sustainability. Occupants suffer from this uncomfortable situation due to the overheating indoor high temperature. This region is located north of Iran, is influenced by humid climate conditions. Adaptation to climate condition in the vernacular architecture of west of Guilan is the main reason of using all these solutions to use the environmental potential for providing comfort for its occupants, which are the main purposes of sustainable development. The research question is how the Guilan's historical architecture has been able to answer the weather conditions. In this research was performed by analysing appropriate climatic solutions in the vernacular architecture of west of Guilan. The methodology based on a Qualitative-interpretative approach was applied. Their location, formation and different functions are investigated. According to this issue, porches and balconies provide best solutions for weather balance conditions in summer and winter and climate comfort.
\end{abstract}

Keywords: Climate Design; Porch; Balcony; Ancient; Vernacular Architecture; Sustainability.

\section{Introduction}

Increase of indoor compared with outdoor temperature is a major concern in modern house design. Occupants suffer from this uncomfortable condition because of over- heating indoor temperature [1,2]. Recognition of porches and balconies using patterns inspired by current conditions can be regarded as important solutions with regards to environmental attributes lead to sustainable development as increase or decrease of indoor temperature in comparison with outdoor temperature has been a significant concern from past ages to come [1], One of the most important environmental issues of today's is preserving environment [3]. As a matter of fact, about $40 \%$ of worldwide energies are consumed in buildings in developed countries $[4,5]$. Balcony designs can be helpful in increasing natural internal air movement they can be taken into consideration on designing [5]. Sustainability is a complex word with a lot of considerations and conceptions; however, the tolerance of ecological pressure in buildings is one of the most important questions included in the meaning of this word, sustainability energy efficient and non-toxic houses and elimination of the usage of non-renewable resources are targets of sustainable architecture On the other hand, Main philosophy of climate reaction design is based on the assessment of the influence of the climate and the optimization of the creation of environmental structures [6]. The indoor climate of an architectural or closed space is influenced by the microclimate

* Corresponding author: mehrinejad.e@gmail.com

\section{http://dx.doi.org/10.28991/cej-03091176}

$>$ This is an open access article under the CC-BY license (https://creativecommons.org/licenses/by/4.0/).

(C) Authors retain all copyrights. 
of the area, on the other hand, environmental conditions and climate are the most important parameters in designing of the buildings. Therefore, buildings are designed to create a comfortable atmosphere for human beings [7, 8]. Through the environmental and design patterns (cultural, physical, and ecological) of each landscape architect or environmental designer, there is a special thinking process among which effective factors and holistic are the most substantial [9]. Connecting to the design environment and context are also important issues that designers should concern [10]. In addition, using low-energy and passive strategies will reduce the need for lighting and air conditioning [11], and preservation of historical monuments not only reflects cultural needs but also responds to the needs of development [2], Identifying and preserving the precious architectural heritage is important in helping to discover the mysteries, secrets, symbols and, signs of past architectural concepts [12]. Studies have been made on the sustainability of ancient houses in Guilan such as [13-18]. Focusing more on the porch [17, 19].

The purpose of this research is to obtain accurate information from native architecture studies, then, studying and analyzing the climate conditions of the ancient houses of western Guilan and comparing the findings with the principles of sustainability. Generally, in this study, we are looking for the reason of the importance of balconies and porches in West Guilan and its relationship with the sustainability factor. This study attempts to answer this question. First, regional vernacular architecture was considered in 2 scales of a) Regional texture and b) Architecture module, and then by using library studies and field studies were analyzed.

\subsection{Sustainable Architecture}

Sustainability is needed to meet the needs of the current world population without the need for future generations [20]. And since the World Commission on Environment and Development, it has gained momentum. Since the Rio Earth Summit of 1992, the concept of sustainability has been widely considered to reduce pollution, resource efficiency, [21]. Many practical measures on sustainability at the community level are taking place with key elements of environmental considerations [22-24].

The basic unit for urban development, as well as the unit of sustainability measurement, is the community. Sustainable development needs to be developed at the community level where the needs, understanding, awareness and, aspirations of local people and authorities in relation to sustainable development must be taken into account and implemented [25]. In addition, in order to improve physical hardware in community building, sustainable community development must also rebuild communities as a result of cultural, geographic and local product issues. A sustainable society additionally, coordinating economic factors and other elements of the natural environment and humanitarian issues, for instance, housing, education, health, access and art [26]. Sustainable development is a kind of development that will meet the needs of the current generation without any problems for the next generation to meet their needs. This definition was expressed by the World Committee on Environment and Development in 1987.

Various scholar's points presented about sustainability by different researchers [5]. Considered the local climate conditions and the integration of the new building with the surrounding. Sam and Hui focused on reducing resource consumption and environmental impacts through collaboration with external climate [6]. Munasinghe has examined the potential impacts of climate change on sustainable development and has focused on climate change and sustainable development, which is constantly interacting [27]. Joshi et al have identified the needs for sustainable development that the reduction of non-renewable resources should be limited to several options [28]. Harris has studied various aspects, such as maintaining a stable source of resources. Avoiding the excessive use of renewable energy sources and reducing unrecoverable resources; promoting the values that encourage consumption standards within the limits of environmental feasibility, and Avoid threats to natural systems that support life on the ground which are among his studies. As well as this [30], Zhang et al have shown that sustained growth emphasizes the preservation and proper use of land, water, and forest as well as other natural resources [30]. Salkin et al focused on all laws and policies that affect environmental quality and the availability of natural resources and provided a minimum standard of protection for human health and the environment [31]. In general, sustainable development has three main bases: environmental protection, cultural and social justice and economic sustainability [6]. Sustainable architecture is based on the fact that we receive what we need in the world. Sustainable buildings are not a formula for salvation; they only create awareness. Therefore, the main goal of the sustainable architecture is to find an architectural solution that includes the conveniences and coexistence of undercover groups. The main goal of sustainable architecture is summarized as protection of resources, saving the resources, designing considering the cycle, and designing with respect to the proper human life. After reviewing these three steps, the architect designs the model with an understanding of the environmental effects of architecture [32].

\subsection{West of Guilan's Background and its Characteristics}

Guilan is located in the south of the Caspian Sea. The rate of rain in this region is the highest rate among other regions of Iran. Due to the specific location of this region between the Caspian Sea and mountains Alborz [33]. Guilan province covers a territory of $14042 \mathrm{~km}^{2}$, extending from 360 34' to $38027^{\prime} \mathrm{N}$ in latitude and $48053^{\prime}$ to 500 34' E in longitude in the Hyrcanian district, covering the eastern one third of the Caspian sea's southern coastline with MSL of -27 m on the plain to $3897 \mathrm{~m}$ on the mountaintop. This region has a specific weather condition with abundant rainfall as well as 
high humidity [34]. Since the existence of the abundant amount of water and rivers in this region, most people are farmers and gardeners, and they specifically cultivate kiwi and also grow sericulture. Most of the towns and villages of Guilan province are built between Rasht and Astara. Figure 1 wherein the past goods were carried from the west to the north of Iran. Therefore, trade and commerce are the other careers of people in the region. In addition, fishing and sericulture and kiwifruit are common seasonal occupants in the region [33].

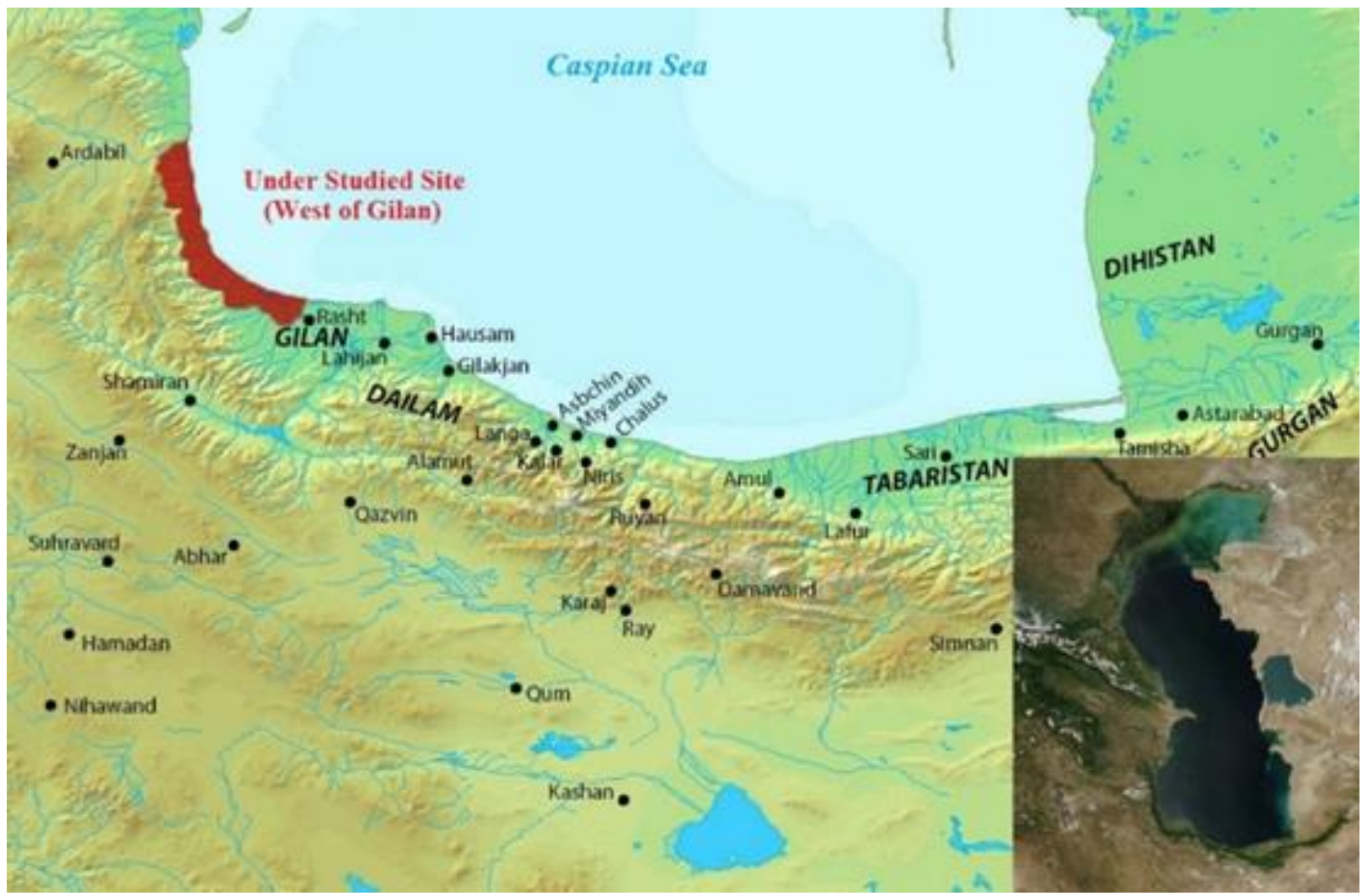

Figure 1. The study area in the south-west of the Caspian Sea (West of Guilan)

\subsection{The Vernacular Architecture in West of Guilan}

\subsubsection{Regional Texture}

Since this area is located near the seashore, and the amount of rainfall is high, the humidity is one of the major problems in the area. Moist air is heavier than dry air and dry air and it indwelled in the underside. Therefore, if urban and rural areas are enclosed, humidity would be accumulated through all the spaces in this region, and breathing and activity would be overwhelming. Thus, it should be taken advantage of airflow in order to prevent the extra moisture to have dwelled in the space.

Consequently, the buildings with courtyards and wide open spaces are constructed separately in this area. The fence around these spaces is often shorter a human. This is due to the airflow to pass through buildings and relocate the humid and stagnant air into the outside of the residential area. Enjoyment of the beautiful and green nature also is another reason for integrating residential environment with nature Figure 2 [35]. It should be noted that in an approach from the countryside and the outskirts to the city center due to the population density and the value of land, the distances between buildings are being shortened [37,38]. This structure is based on the climatic conditions, quite on the contrary with the surrounded and closed texture of urban and rural areas in hot and cold climate and hot and dry climate, which have compact and dense texture [38]. 


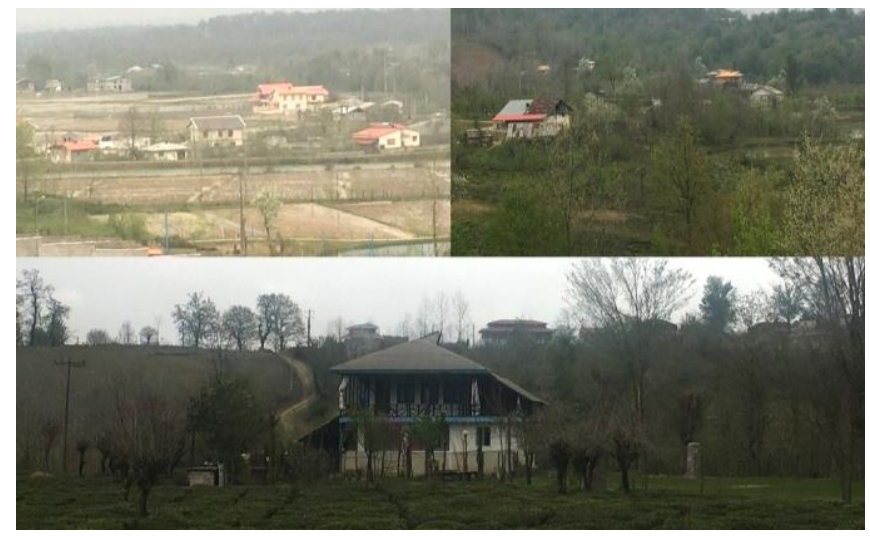

Figure 2. The Separate texture of houses

\subsubsection{The Scale of the Architectural Unit}

Some of the most important attributes of Guilan, which impacts on the architecture of this region, are summarized as abundant rainfalls in all seasons especially autumn and winter, low-temperature differences between nights and days in all seasons. Therefore, construction of balconies in this rainy region is considered an important matter to prevent rain penetrations into the interior spaces, reduce the humidity, and entrance of north-east winds to the interior spaces in summer. Thus, it is obvious that why most of the balconies are located on the east side in this region.

It is important for the vernacular architecture of Guilan to provide ventilation to reduce the humidity. Thus, to reduce the humidity by north-east winds and to protect the structures from north-west rainy winds, tall buildings with open spaces and east-west extensions are constructed Balconies are the main reasons of air ventilation in these houses by circulating the favourable north-east winds. It prevents air stagnation in humid climates [39].

Due to the humidity in mountainous areas, under the balcony and porch in the first and second floor, storage built from local stiff materials was created Figure 3. In other areas of study, porches were built on the seat in order to prevent the entrance of the moisture into the building [35]. Private rooms and bedrooms were located upstairs. Furthermore, in most cases, the first floors were allocated to public spaces. Empty spaces under the floors were used as storages

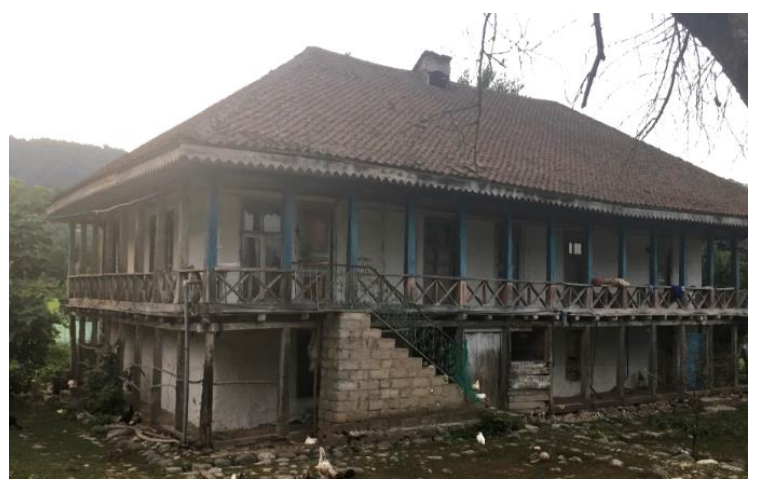

Figure 3. Vernacular house

\subsection{The Main Elements of Vernacular Architecture in Guilan}

\subsubsection{Porch}

Porch, as a semi-open space, is the most prominent and commonplace spaces serve several functions. Due to lowtemperature fluctuations and climate sustainability from March to November, many activities such as housework 9 cooking, living, eating and even sleeping are done at porches [40]. Porches, by width of at least 2 to 2.5 meters, are located at the length of buildings and by connecting the indoor room with the outside, it causes air circulation Figure $9 \mathrm{~b}$. Situating on the south side of the building, porch or hall allows the sun to create a favorable shadow in the summer because of the vertical shine of the sun on the roof. Moreover, the sun causes heat absorption in winter because of diagonal radiation Figure 4 [40].

In addition, sometimes porch has economical functions besides its use as living space, storage, and service area. In addition to rest in summer at the east hall (i.e. east balcony at the second floor in which air vents easily), as well as this it can be used as storage in winter [42]. Due to rainfalls, main rooms are located at the second layers and protected from rains by porches Figure 4a, which is located around the building and/or at least it is located at south and east of the building. This space prevents the penetration of summer hot weather into the main space of buildings. The most important space is a semi-open space with multi-season functions; it opens from two or three sides, especially 
the south and east. Therefore, the main porch as the living room is larger and higher than all the other spaces to have better view and ventilation, which is also decorated by wooden fences and hanging vases [36, 39, 40].

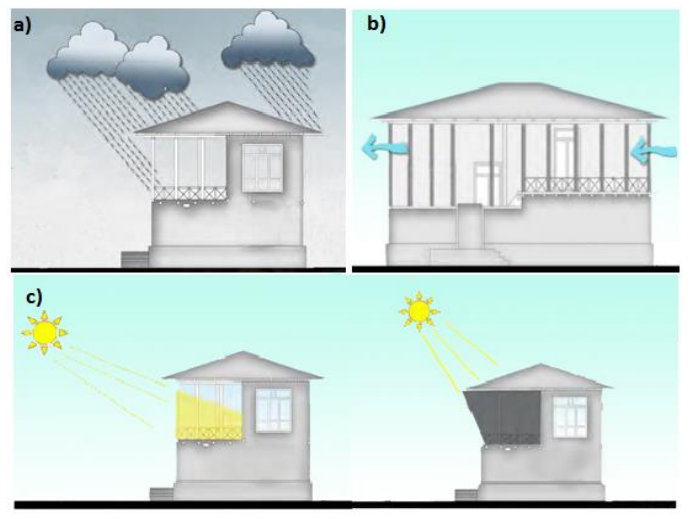

Figure 4. a) The role of the porch as an air conditioner; b) The role of the porch in rain protection; c) The role of the porch in the south corner of a building in summer and winter (Produced by the authors)

\subsubsection{Balcony and Passageway}

Balconies of the second and third floors are called hall. Hall is higher than a balcony and usually barn or stable are placed under the hall, however, in some cases under the hall is empty. The room behind the hall is also called attic [36]. Most of the times, the main balcony is located southward due to wind, rain and, sunlight rising in winter. Buildings by two floors halls are commonplace, in compare, because of abundant winds in autumns, those of the three floors are not widespread. Moreover, downstairs are called winter-stay, however, upstairs by balconies and passageways are called summer-stay [42].

The space by the width of 1 to 1.5 meters at the backward of balconies prevents the direct and intense sunlight to building walls, which is called passageway Figure 5. The main roles of passageways are protection from rainfalls and direct sunlight in summer, shading in summer, air conditioning, and circulation of summer breezes into the building are. This space is suitable for hanging home-made products such as garlic, pumpkin, vase, and etc. to dry products and beautify the interior view of buildings [42].
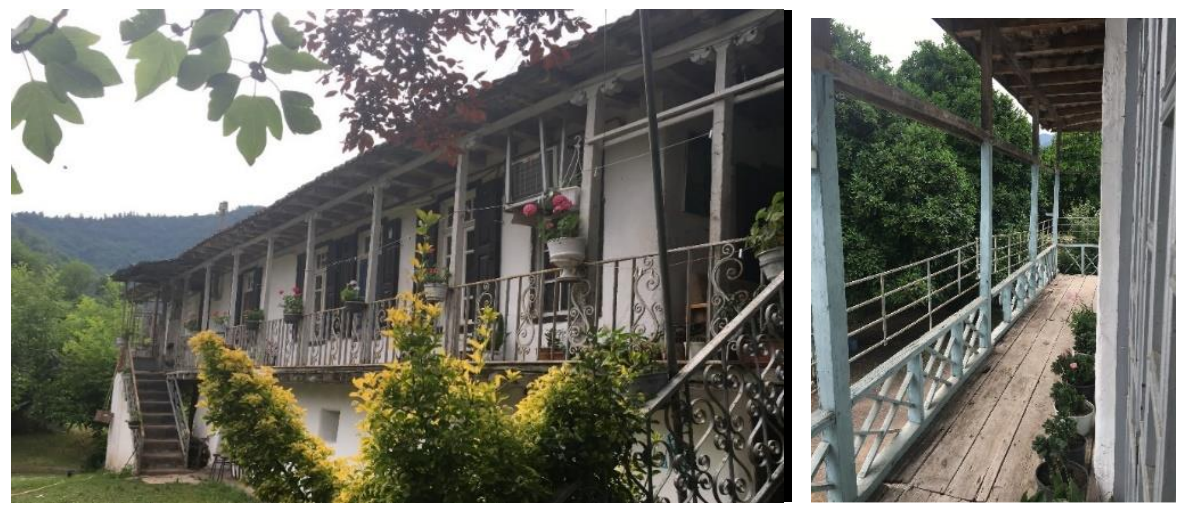

Figure 5. Vernacular house

\section{Methodology}

Considering the importance of sustainability debate in recent years, Has been studied a historical study of the native architecture of western Guilan. In which are discussed the importance and the sustainability of the porches of the houses in the area. The research methodology is a qualitative research, first began with library studies and Data collection and computing meteorological data for the last 8 years of the study area. Based on the daily data received from meteorological data, the monthly average of the weather is obtained in the form of Excel charts After field observations, using the AutoCAD software and sample case analysis were analyzed. Comparing the results obtained from the 8-year weather region with a case study shows the correlation between historical buildings and the water conditions in the area.

\section{Result}

\subsection{Climate Result}

Figures 6 to 10 show different factors affect in climate study in the past 8 years (2009-2016) in the understudy area, Khotbehsara. Figures 6 and 7 demonstrate the maximum and minimum averages of temperature in each month and 
annual amounts in the past 8 years, respectively. Moreover, Figure 8 shows changes of wind blow in the case of monthly and annual average amounts. Figure 9 shows relative humidity in the past 8 years.

According to Figure 6 the average amounts of maximum temperature in the studied area during 2009 to 2016 were almost similar. The average amount of maximum temperature in the past 8 years reached the highest point in August at $34.3^{\circ} \mathrm{C}$, while the lowest amount was in February at $11^{\circ} \mathrm{C}$.

Figure 7 shows the average amounts of minimum temperature in the past 8 years. Similar to the Figure 6 , the average amounts of minimum temperature during 2009 to 2016 were almost similar, however, the results of 2009 provided the lowest amounts compared to other years. It can be seen that August and February had the lowest and highest values of average amounts of minimum temperature at 24 and $6{ }^{\circ} \mathrm{C}$, respectively.

Based on Figure 8, the recorded data in the mid-year (i.e. May to August) had been less than the other months. For instance, the minimum and maximum values of average amounts of wind blow were reported in July and October at 9 and $14 \mathrm{kph}$, respectively.

High relative humidity is another significant factor of climate changes in the studied area. As shown in Figure 9, the relative humidity was more than $60 \%$ in all of the studied years. It can be seen that July and October experienced the minimum and maximum amounts of average relative humidity at 64 and $78 \%$, respectively.

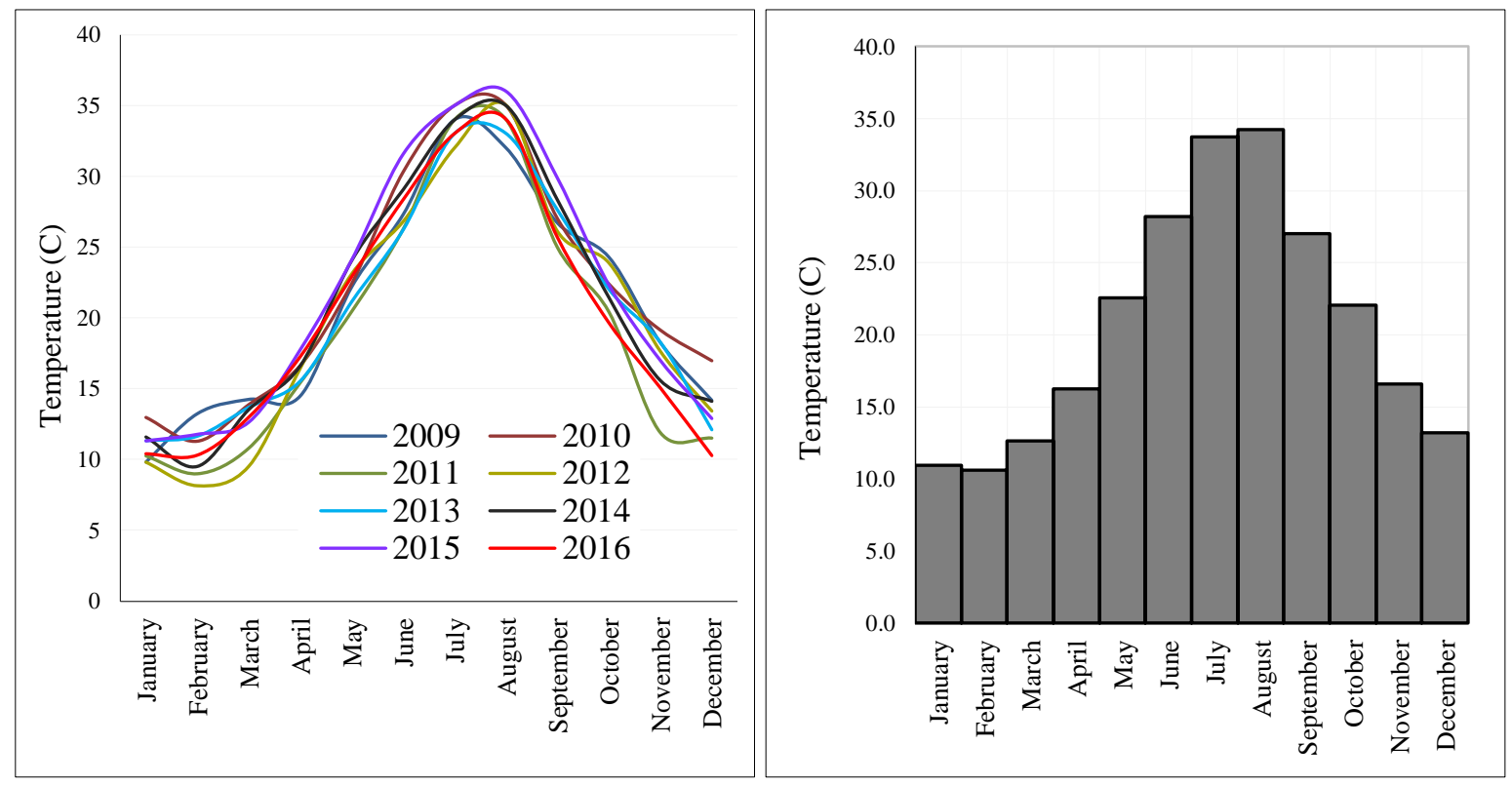

Figure 6. Monthly average amount of maximum temperature and annual average amounts over past 8 years
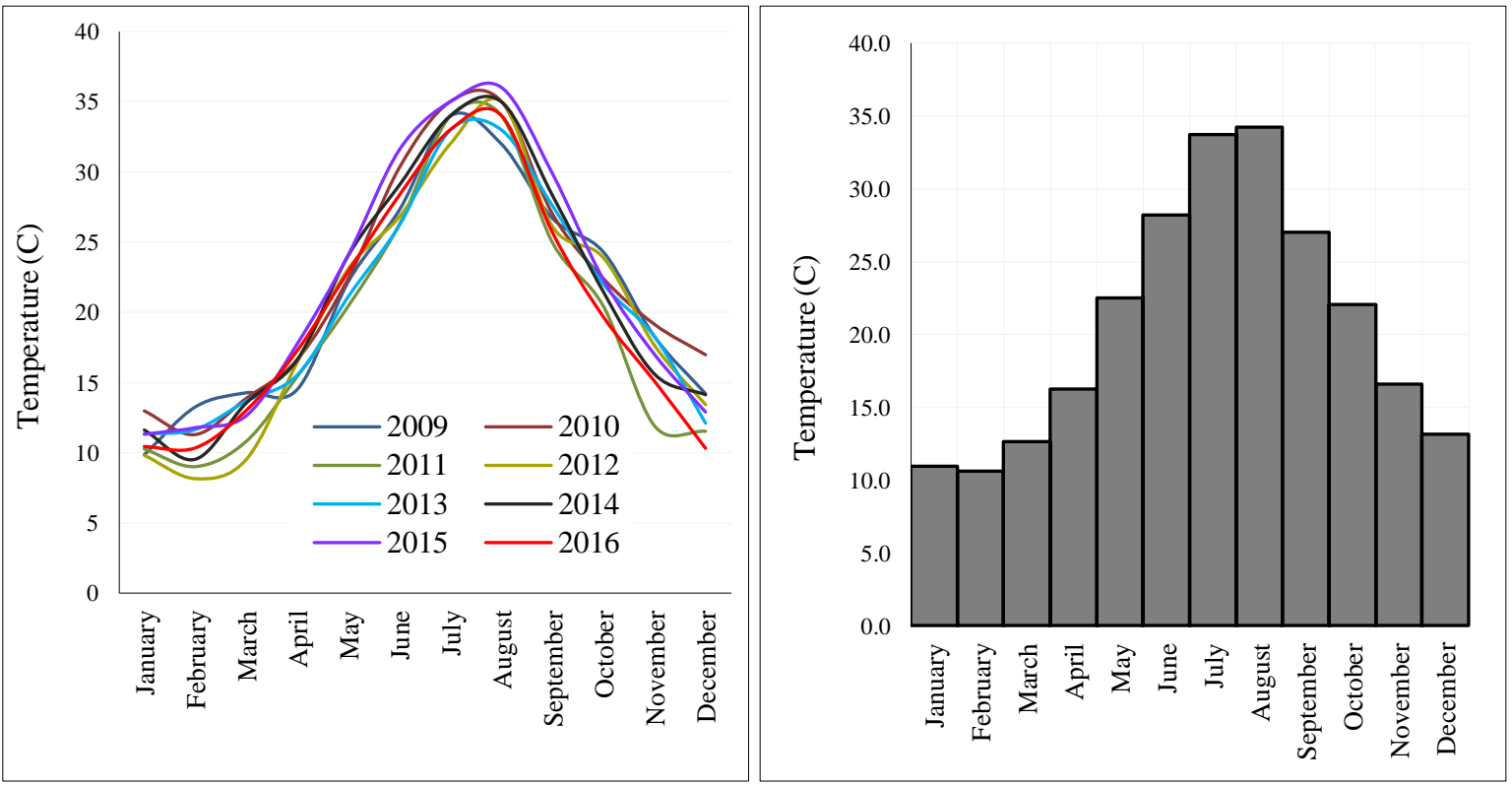

Figure 7. Monthly average amount of minimum temperature and annual average amounts over past 8 years 

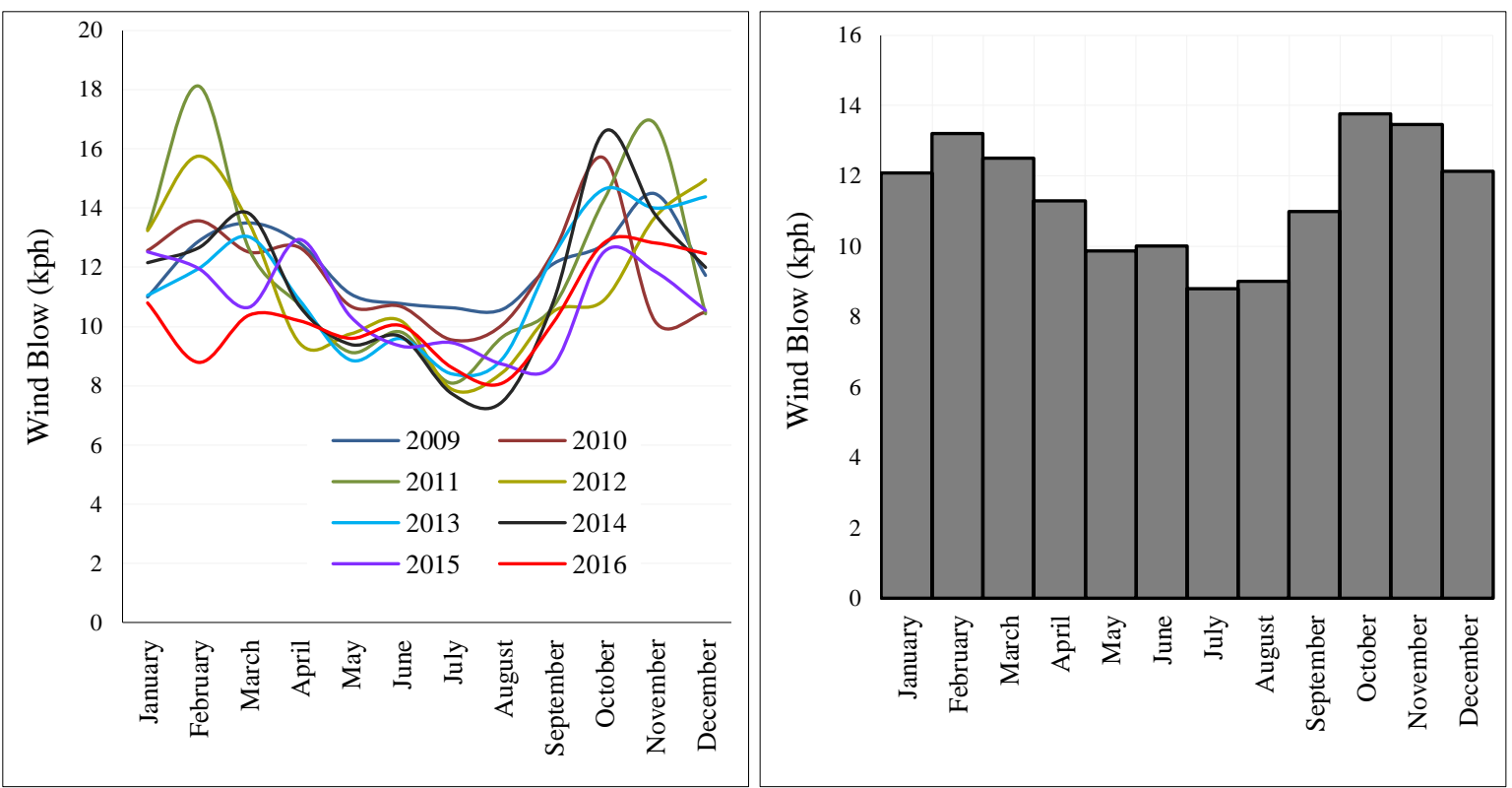

Figure 8. Monthly average amount of wind blow and annual average amounts over past 8 years.

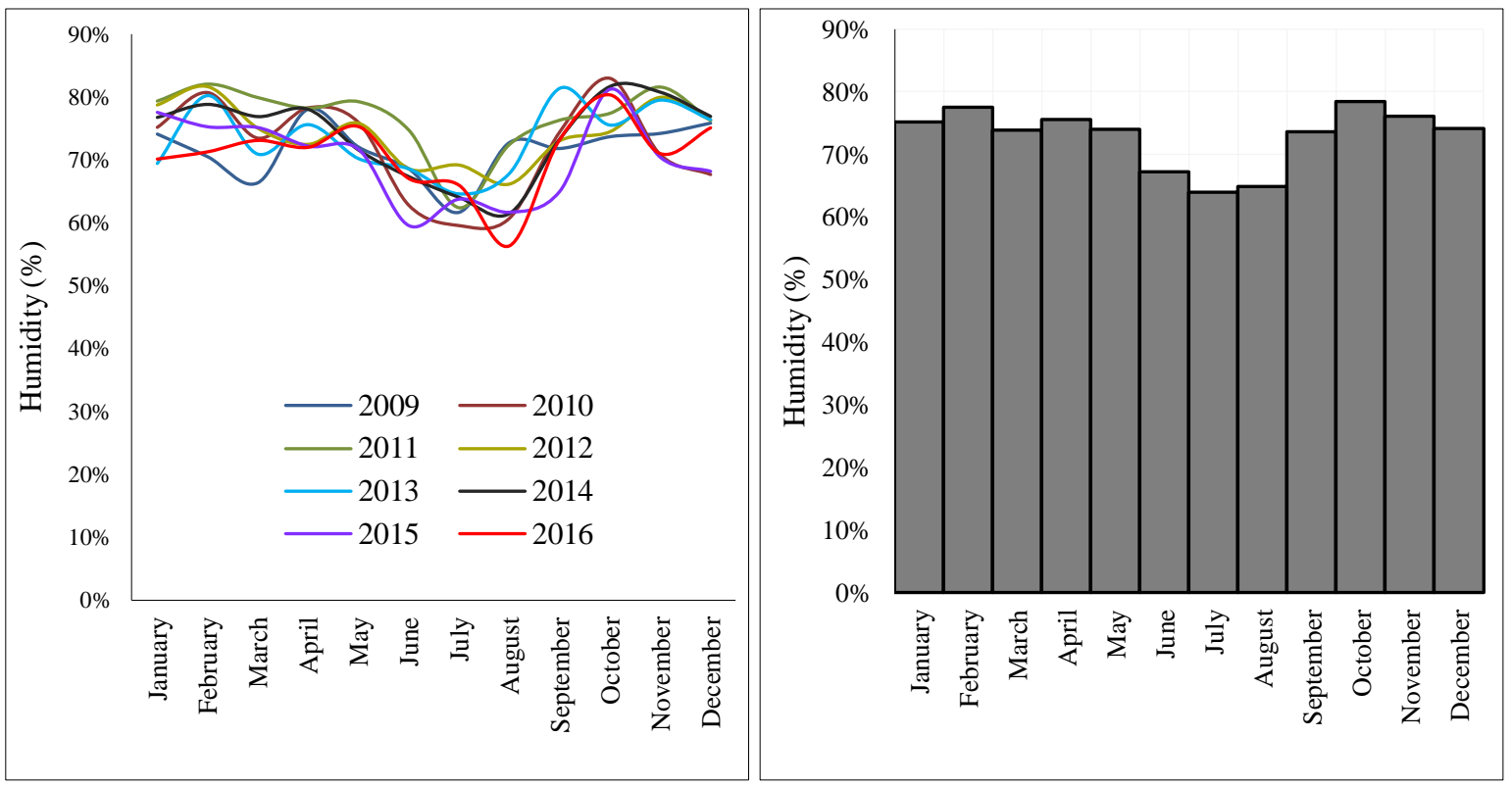

Figure 9. Monthly average amount of humidity and annual average amounts over past 8 years

\section{Discussion}

\subsection{Effective Climate Factors of Balconies and Porches in the West of Gilan (Lisar), Central of the West of Guilan}

Based on the territorial studies on the site and also, according to Figure 9, it is obvious that average humidity was observed at 74\% during the 8 previous years (i.e. 2009 to 2016) that is out of the comfort range [43, 44]. Therefore, construction of porches and balconies is a significant issue in the understudied region to have a weather exchange and to prevent stagnating of humid weather. Besides the aforementioned points about the mild weather of the site, it has the highest amount of rainfall compared to other places in Iran. Thus, to prevent disturbing winds from west and north in autumns and winters, which affect the direction of rain, porches and balconies are constructed against the wind directions.

One of the most significant reasons for the construction of balconies and porches are the eastern-side-winds, which known as desired winds in springs and summers. Besides the high degrees of humidity in the site, weather high temperature especially in July and August at $34{ }^{\circ} \mathrm{C}$ during the previous 8 years is another disturbing factor Figure 6 . The resulting temperature indicates no thermal comfort [43-45] Because of vertical sunshine on the roofs in summers and higher absorption of sunlight on the porches and balconies due to the inclined sunshine in winters, construction of balconies and porches at both eastern and southern sides of houses can be observed in the traditional architecture of the 
site Figure 5. It is worth adding that porch and balcony are located at the eastern and southern sides or even they are attached to each other like the letter "L".

\subsection{Study of a Case in Khotbehsara}

This study is concentrated to the western side of the Caspian Sea (i.e. west of Guilan). Based on the recorded meteorology data and geographic situations of the western side of the Caspian Sea, climate terms of different parts of the site are almost similar. Thus, for more concentration on the site, all of the studied parameters are considered for the region known as Khotbesara. Therefore, for a better understanding of climate changing, meteorology data of the site are studied.

Figure 11 indicates a view of the vernacular house, also Figure 12 shows the plan and elevation of the house. From Figure 10, the porch and balcony are located in the east side of the house. In the most favorable climate zone of the region, in order to enjoy natural ventilation, these results are consistent with previous studies [39-41] Stone, river stone, sand from Caspian Sea, lime, and wood of local trees were most rampant materials for the construction of balconies and porches [38]. The porch that is located at the Downstairs and center of this building has been used in winters. The main reasons for using the porch in winters is that it has thick walls at both sides, which minimize the air exchanges with the cold weather of outside. The other reason is that it is located on the ground by some elevation that has less airflow in comparison with upstairs. It can be seen from the Figures 10 and 11, the entrance steps through the space divider has access to the porch on one side and the balcony on the other side. As balcony is located higher than the porch, airflows and favorable winds of east provide comfortable conditions for resting and living at there in summers. Supports previous findings downstairs are called winter-stay, however, upstairs by balconies and passageways are called summer-stay [42].

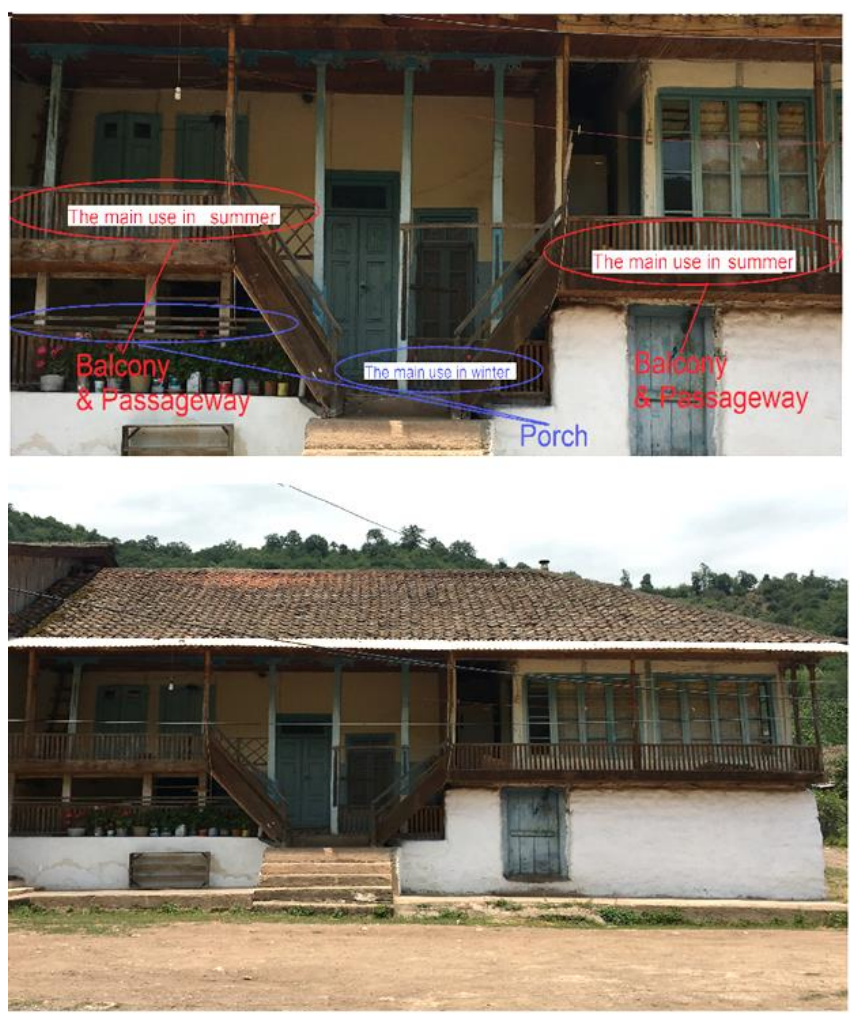

Figure 10. A vernacular house in Khotbehsara, west of Guilan, Iran
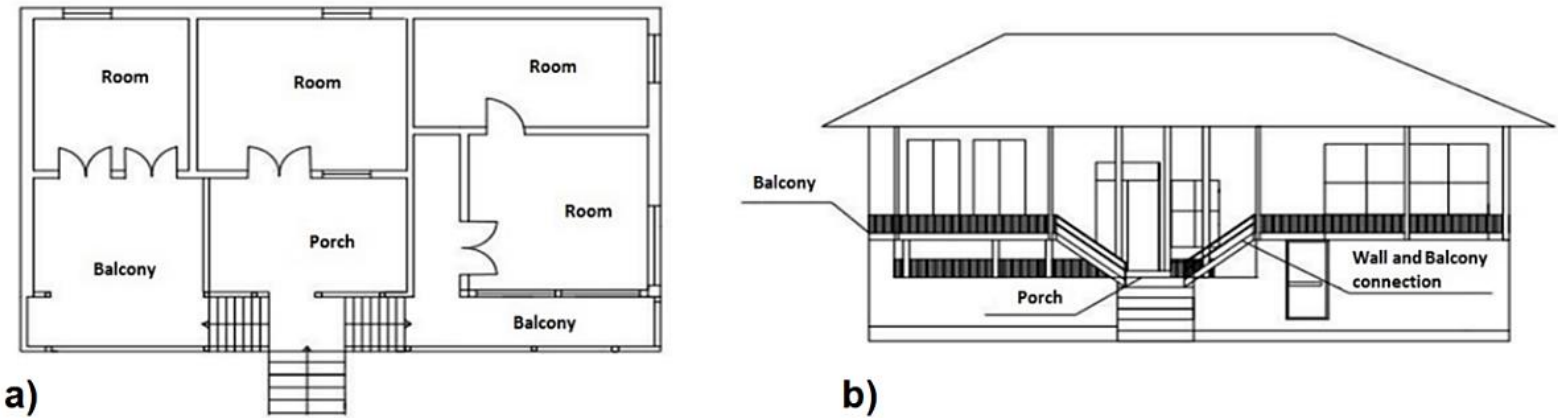

b)

Figure 11. a) Plan of the vernacular house in Khotbehsara and b) Elevation of the vernacular house in Khotbehsara 


\section{Conclusion}

In this research analysis of appropriate climatic solutions in the vernacular architecture of west of Guilan with its specific weather conditions represents various solutions to provide humans with comfortable conditions. Evidence has been obtained in the past 8 years relative humidity was more than $60 \%$ in all of the studied years Figure 9 . The minimum and maximum amounts of average relative humidity at $64 \%$ and $78 \%$ and the average amount of maximum temperature reached the highest point in August at $34.3{ }^{\circ} \mathrm{C}$, while the lowest amount was in February at $11^{\circ} \mathrm{C}$ Figure 6,7 . The following results can be drawn from this research:

- Vernacular architecture in the west of Guilan to climate responsive design has obvious approaches for sustainability. The creation of porch and balcony with a specific form, direction and adaptable with climate conditions decrease energy consumptions and prevent air pollution in the region and reduce the mental and physical damages. Local residents in this area used some climatically adjustable solutions in order to maintain their buildings from humid and rainy climate. They built their houses based on the optimum air circulation, desirable wind flow and shadow, and confronting unfavourable diagonal winds. In this regard, porch and balcony were suitable solutions. Some of the most important methods for adaptability with climatic factors are shown in Table 1.

Table 1. Features of the balcony and porch in the west of Guilan affected by the climate

\begin{tabular}{ll}
\hline \multicolumn{1}{c}{ Climate features } & \multicolumn{1}{c}{ Physical features } \\
\hline - Shading in summer & $\begin{array}{l}\text { - Creating a semi-open space in the eastern and } \\
\text { southern sides }\end{array}$ \\
- Create an atmosphere suitable for daily activities & $\begin{array}{l}\text { - Taking advantage of the cool wind from North East } \\
\text { - Avoid the rainy and particularly uncomfortable Northwest rain in } \\
\text { the winter to residential space }\end{array}$ \\
- Creating profit double airflow which raise the temperature of the & $\begin{array}{l}\text { outdoor to semi-open and closed } \\
\text { comfort to some degree }\end{array}$ \\
\end{tabular}

- Houses in this region are not used as enclosed spaces. Porch and balcony elements cause to the integration of public and private spaces and this integration has created an eccentric architecture.

\section{References}

[1] Roslan, Q., Ibrahim, S.H., Affandi, R., Nawi, M.N.M. and Baharun, A. A literature review on the improvement strategies of passive design for the roofing system of the modern house in a hot and humid climate region. Frontiers of Architectural Research 5, no. 1 (2016): 126-133. doi:10.1016/j.foar.2015.10.002.

[2] Daemei, Abdollah Baghaei, Maryam Azmoodeh, Zahra Zamani, and Elham Mehrinejad Khotbehsara. "Experimental and simulation studies on the thermal behavior of vertical greenery system for temperature mitigation in urban spaces." Journal of Building Engineering 20 (2018): 277-284. doi:10.1016/j.jobe.2018.07.024

[3] Edwards, B. Rough guide to sustainability: A design primer. London: "RIBA Publishing, First Edition” (2014). 978-1859465073.

[4] Aflaki, Ardalan, Norhayati Mahyuddin, Zakaria Al-Cheikh Mahmoud, and Mohamad Rizal Baharum. "A review on natural ventilation applications through building façade components and ventilation openings in tropical climates." Energy and Buildings 101 (2015): 153-162. doi:10.1016/j.enbuild.2015.04.033.

[5] Khotbehsara, Elham Mehrinejad, Pegah Eghbal, and Sara Nourmusavi Nasab. "Porch and balcony as sustainable architecture factors in vernacular houses of west of Guilan: Case studies in Khotbehara, Iran." World Rural Observations 8 (2016): 48-56.

[6] Hui, S. C. M. "Sustainable building technologies for hot and humid climates." In Invited Paper for the Joint Hong Kong and Hangzhou Seminar for Sustainable Building, pp. 21-23. 2007.

[7] Givoni, Baruch. "Comfort, climate analysis and building design guidelines." Energy and buildings 18, no. 1 (1992): 11-23. doi:10.1016/0378-7788(92)90047-k.

[8] Motealleh, Parinaz, Maryam Zolfaghari, and Mojtaba Parsaee. "Investigating climate responsive solutions in vernacular architecture of Bushehr city." HBRC journal (2016). doi:10.1016/j.hbrcj.2016.08.001.

[9] Khakzand, Mehdi. "An Exploration of a Socio-Cultural Approach Using Significant Variables of Pattern Language amongst Iranian Experts of Environmental Design." Journal of Asian Architecture and Building Engineering 13, no. 2 (2014): $295-302$. doi:10.3130/jaabe.13.295.

[10] Alexander, C. The timeless way of building. Oxford University Press, New York, 1979. 978-0195024029

[11] Afshari, Hoda. "Design fundamentals in the hot and humid climate of Iran: the case of Khoramshahr." Asian Culture and History 4, no. 1 (2012): 65. doi:10.5539/ach.v4n1p65

[12] Sartipipour M. Rural housing indicators in Iran. In: Honar-Ha-Ye-Ziba, University of Tehran, Tehran, 2005; 22, pp. 43-52.

[13] Mottaki, Zoheir, and Iman Amini. "Cultural Sustainability Patterns in Vernacular Architecture: A Case Study of Gilan, Iran." 
GSTF Journal of Engineering Technology (JET) 2, no. 1 (2017). doi:10.5176/2251-3701_2.1.41.

[14] Nia, Ensieh Ghorbani. "Architectural Structure and Environmental Performance of Sustainable Lahijan Vernacular Settlements, N Iran." International Journal of Environmental Protection 3, no. 1 (2013): 15.

[15] Kakouei, M., Kakouei, M., Suberamanian, K., Kahn, S. M., Jahangirzadeh, A., \& Akib, S. (2012, November). Masouleh: A City; A History. In Proceedings of World Academy of Science, Engineering and Technology World Academy of Science, Engineering and Technology (WASET), (2012): 71- 491.

[16] Foroughi, Reza. "Climate-responsive Strategies in Vernacular Houses in Northern Iran (Gilan)." International Journal of the Constructed Environment 8, no. 2 (2016). doi:10.18848/2154-8587/cgp/v08i02/15-26.

[17] Daneshjou, Khosro, and Seyed Majid Mofidi Shemirani. "A comparative study of vernacular architecture compatible with mild and humid weather in Gilan's Western plains (Case study: Gasht, Shalma and Gilandeh villages)." International Journal of Architecture and Urban Development 7, no. 3 (2017): 9-16.

[18] Ghasemi, Farid. "Clean Energy Efficiency of Vernacular-Traditional Architectural Indicators for the Development of Sustainable Tourism." Journal of Sustainable Development 10, no. 3 (2017): 250. doi:10.5539/jsd.v10n3p250

[19] Jalili, Tooraj, and Arezo Azar. "Study of indigenous patterns of climate in traditional architecture of north of iran in order to develop the concept of sustainability in the field of contemporary (case study: architecture of Gilan, Iran province)." Journal of Current Research in Science 2 (2016): 131.

[20] Keeble, B. R. The Brundtland report:'Our common future'. Medicine and War (1988); 4: 17-25.

[21] London Department of the Environment, T. A. T. R. Building a Better Quality of Life: a Strategy for More Sustainable Construction. Department of the Environment, T. A. T. R. L. (Ed.). DETR, London (2000).

[22] Newman, Lenore, and Ann Dale. "The role of agency in sustainable local community development." Local environment 10, no. 5 (2005): 477-486. doi:10.1080/13549830500203121.

[23] Huang, Zishuo, Hang Yu, Zhenwei Peng, and Mei Zhao. "Methods and tools for community energy planning: A review." Renewable and sustainable energy reviews 42 (2015): 1335-1348. doi:10.1016/j.rser.2014.11.042

[24] Soflaei, Farzaneh, Mehdi Shokouhian, and Amir Soflaei. "Traditional courtyard houses as a model for sustainable design: A case study on BWhs mesoclimate of Iran." Frontiers of Architectural Research 6, no. 3 (2017): 329-345. doi:10.1016/j.foar.2017.04.004.

[25] Yuan, W., P. James, K. Hodgson, S. M. Hutchinson, and C. Shi. "Development of sustainability indicators by communities in China: a case study of Chongming County, Shanghai." Journal of Environmental Management 68, no. 3 (2003): $253-261$. doi:10.1016/S0301-4797(03)00063-X.

[26] Hsueh, Sung-Lin, and Min-Ren Yan. "Enhancing sustainable community developments a multi-criteria evaluation model for energy efficient project selection." Energy Procedia 5 (2011): 135-144. doi:10.1016/j.egypro.2011.03.025

[27] Munasinghe, M. Climate change and sustainable development linkages: Points of departure from the ipcc tar. Integrated SD and CC in the IPCC AR4, Geneva, (2007).

[28] Carpentier, Sally, Mridula Nath Chakraborty, Margaret Daymond, Michael Griffiths, Philip Holden, Dougal McNeill, Grace Musila et al. "XVIII New Literatures." The Year's Work in English Studies 94, no. 1 (2015): 1099-1233.

[29] Harris, Jonathan M. "Sustainability and sustainable development." International Society for Ecological Economics 1, no. 1 (2003): $1-12$.

[30] Zhang, Q., \& Crooks, R. Toward an environmentally sustainable future: Country environmental analysis of the People's Republic of China. Asian Development Bank, (2012). 978-92-9092-712-9.

[31] Dernbach, J. C., Salkin, P. E., \& Brown, D. A.. "Sustainability as a Means of Improving Environmental Justice." J. Envtl. \& Sustainability L. 19 (2012): 1.

[32] ÇELEBİ, Gülser. "Environmental discourse and conceptual framework for sustainable architecture." Gazi University Journal of Science 16, no. 1 (2003): 205-216.

[33] Tahbaz, M., Jalilian, Sh. Architectural principles of harmony with the climate in the approach to the architecture of the mosque. Shahid Beheshti University Publication, Tehran, Iran, (2008). 9789644571398

[34] Jafari, Meisam, Hamid Majedi, Seyed Masoud Monavari, Ali Asghar Alesheikh, and Mirmasoud Kheirkhah Zarkesh. "Dynamic Simulation of Urban Expansion through a CA-Markov Model Case Study: Hyrcanian Region, Gilan, Iran.” European Journal of Remote Sensing 49, no. 1 (January 2016): 513-529. doi:10.5721/eujrs20164927.

[35] Zomarshidi, H. Iran's architecture, implementation of building with traditional materials, Zomorod Publication, Pages, Tehran, iran, (2013).

[36] Memarian, G. "Introduction to House typology in Iran, Courtyard houses." Iran University of Science and technology (1994).

[37] Naqinezhad, A., A. Ghahreman, and M. Assadi. "Some new record species for the flora of Iran as well as ecological and phytogeographical notes." Iran J Bot 11 (2005): 89-95.

[38] Ghobadian, V. Climate study of traditional buildings of Iran, Tehran University Publication: Tehran, Iran, (2013). 9789640338735

[39] Rezazadeha, Narges, and Hossein Medib. "Thermal Behavior of Double Skin Facade in Terms of Energy Consumption in the 
Climate of North of Iran-Rasht." Space Ontology International Journal 6, no. 4 (2017): 41-56.

[40] Miryousefi, P. "Rural Eco-Museums: Tourism Development Based on Sustained Development Models." The Sustainable World (September 30, 2010). doi:10.2495/sw100621.

[41] Khakpour, M. Construction of nice houses in Guilan. Journal of beautiful arts 25, (2005):24-54.

[42] Khakpour, M. Vernacular houses in villages of Guilan. Journal of beautiful arts 22, (2006): 63-72.

[43] Nicol, Fergus, Michael Humphreys, and Susan Roaf. Adaptive thermal comfort: Foundations and analysis. Routledge, 2015.

[44] Parsons, Ken. Human thermal environments: the effects of hot, moderate, and cold environments on human health, comfort, and performance. CRC press, 2014.

[45] Spagnolo, Jennifer, and Richard De Dear. "A field study of thermal comfort in outdoor and semi-outdoor environments in subtropical Sydney Australia." Building and environment 38, no. 5 (2003): 721-738. doi: 10.1016/S0360-1323(02)00209-3 